\title{
SKETSA DAKWAH DAN PEMBINAAN QURANI MASYARAKAT DESA MANGELORENG MELALUI KKN STIBA MAKASSAR
}

\author{
Ariesman \\ Sekolah Tinggi Ilmu Islam dan Bahasa Arab (STIBA) Makassar \\ ariesman@stiba.ac.id
}

Keywords :

Preaching, Construction,

Quranic, Mangeloreng

\section{ABSTRACT}

Malerongeng Village is an area with a relatively strong level of religiosity. Religious culture, preserving the zikkiri tradition 'to the point that religious leaders are the most prominent in this village. The purpose of the STIBA Makassar Class III Real Work Lecture $(K K N)$ is as a form of community service which is a pillar of the tri dharma of higher education. The method of implementing community service in the Mangeloreng Village begins with mapping the problems and needs of the community by using instruments that are made independently combined with SOAR analysis. After the analysis is carried out, a work program (proker) is prepared which is adaptive in the community. The work program successfully launched by the third generation of STIBA Makassar KKN students in Mangeloreng Village is socialization and friendship (SS), TK / TPA inauguration, TK / TPA inauguration, elementary / junior high school teaching, Arabic language learning group (KBBA), Santri festival (FS)), and dirosa learning (PD). The results of the implementation of this Community Service program are that the interest and enthusiasm of the children (santri) has progressed in learning the Qur'an, religious knowledge, and Arabic. This can be marked by the increase in the number of students studying Koran at the TPA, the Arabic learning group and the inauguration of 1 new TPA, as well as the support of parents of students who fully appreciate the educational programs of STIBA Makassar KKN students. The development of the Koran skills was also seen in the adult al-Qur'an study group (Dirosa), the markers were proficiency in the recitation of Makhraj and Tajweed.

\begin{tabular}{ll}
\hline Kata kunci : & \multicolumn{1}{c}{ ABSTRAK } \\
\cline { 2 - 3 } Dakwah, Pembinaan, Qur'ani, & $\begin{array}{l}\text { Desa Malerongeng merupakan daerah yang tergolong tingkat } \\
\text { Mangeloreng }\end{array}$ \\
& zikkigiusitasnya cukup kuat. Budaya religius, mepertahankan tradisi \\
& menonjol di desa ini. Tujuan dari Kuliah Kerja Nyata (KKN) STIBA \\
& Makassar angkatan III ini adalah sebagai wujud pengabdian kepada \\
& masyarakat yang merupakan pilar dari tri dharma perguruan tinggi. \\
& Metode pelaksanaan pengabdian kepada masyarakat di Desa \\
& Mangeloreng diawali dengan memetakan masalah dan kebutuhan \\
& masyarakat dengan menggunakan instrumen yang dibuat secara \\
& mandiri berpadu analisis SOAR. Setelah analisis dilakukan, maka \\
& disusun program kerja (proker) yang adaptif struktur di masyarakat. \\
& Program kerja yang berhasil dicanangkan oleh mahasiswa KKN \\
& STIBA Makassar angkatan III di Desa Mangeloreng adalah \\
& sosialisasi dan silaturahim (SS), pembinaan TK/TPA, peresmian \\
TK/TPA, pengajaran SD/SMP, kelompok belajar bahasa arab \\
(KBBA), festival santri (FS), dan pembelajaran dirosa (PD). Hasil \\
dari pelaksanaan KKN ini adalah terlihat minat dan antusiasme anak-
\end{tabular}

Kata kunci :

Dakwah, Pembinaan, Qur'ani, Mangeloreng
Desa Malerongeng merupakan daerah yang tergolong tingkat
religiusitasnya cukup kuat. Budaya religius, mepertahankan tradisi
zikkiri' hingga pada menokohkan tokoh agama adalah yang paling
menonjol di desa ini. Tujuan dari Kuliah Kerja Nyata (KKN) STIBA
Makassar angkatan III ini adalah sebagai wujud pengabdian kepada
masyarakat yang merupakan pilar dari tri dharma perguruan tinggi.
Metode pelaksanaan pengabdian kepada masyarakat di Desa
Mangeloreng diawali dengan memetakan masalah dan kebutuhan
masyarakat dengan menggunakan instrumen yang dibuat secara
mandiri berpadu analisis SOAR. Setelah analisis dilakukan, maka
disusun program kerja (proker) yang adaptif struktur di masyarakat.
Program kerja yang berhasil dicanangkan oleh mahasiswa KKN
STIBA Makassar angkatan III di Desa Mangeloreng adalah
SOsialisasi dan silaturahim (SS), pembinaan TK/TPA, peresmian
TK/TPA, pengajaran SD/SMP, kelompok belajar bahasa arab
(KBBA), festival santri (FS), dan pembelajaran dirosa (PD). Hasil
dari pelaksanaan KKN ini adalah terlihat minat dan antusiasme anak- 
anak (santri) mengalami kemajuan dalam mempelajari al-Qur'an, ilmu agama, dan bahasa Arab. Hal ini dapat ditandai dengan bertambahnya jumlah santri yang belajar mengaji di TPA, kelompok belajar bahasa Arab dan diresmikannya 1 TPA baru, serta dukungan orang tua santri yang mengapresiasi penuh program-program edukatif mahasiswa KKN STIBA Makassar. Perkembangan keterampilan mengaji juga tampak terlihat pada kelompok belajar alQur'an orang dewasa (Dirosa), penandanya adalah kemahiran dalam pelafalan makhraj dan tajwid.

\section{PENDAHULUAN}

Mangeloreng adalah nama sebuah desa yang berada di wilayah kecamatan bantimurung, kabupaten Maros, provinsi sulawesi selatan, indonesia. Desa mangeloreng berstatus sebagai desa defenitif dan tergolong pula sebagai desa swadaya. ${ }^{1}$
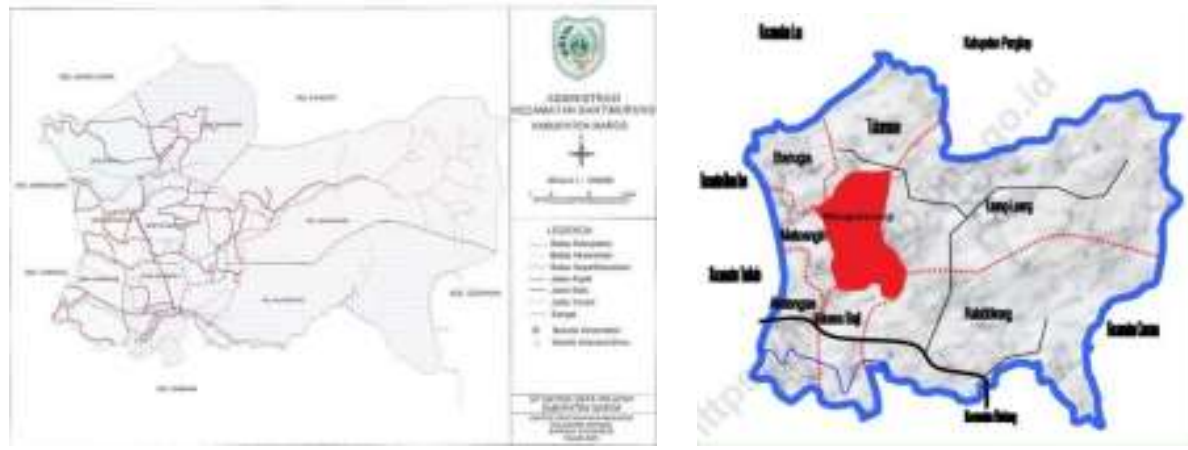

Peta administrasi kec.bantimurung

Maroskab.bps.go.id Gambar 1.1 Peta Desa Mangeloreng

Letak Geografis: Desa Mangeloreng adalah salah satu dari 6 desa dan 2 kelurahan dalam wilayah pemerintahan Kecamatan Bantimurung Kabupaten Maros yang terletak $\pm 2 \mathrm{~km}$ sebelah utara dari jln poros Bantimurung Bone Provinsi Sulawesi Selatan. Secara administrative mangeloreng memiliki luas wilayah desa $8,72 \mathrm{~km}^{2}$ dan luas hutan $150 \mathrm{~km}^{2}$ yang terletak disebelah timur Ibukota kabupaten Maros dengan jarak $10 \mathrm{Km}$. Kondisi Alam Desa Mangeloreng adalah Pertanian dan Perkebunan, sebagian besar daratannya berupa persawahan, yang sistem tanamnya dengan sistem tadah hujan. ${ }^{2}$

Adapun batas wilayah Desa Mangeloreng adalah dari sebelah utara berbatasan dengan Desa Tukamasea Kabupaten Bantimurung; sebelah selatan berbatasan dengan Desa Minasabaji Kabupaten Bantimurung; sebelah timur berbatasan dengan Kelurahan Kalabbirang Kabupaten Bantimurung; sebelah barat berbatasan dengan Desa Mattoanging Kabupaten Bantimurung. Adapun jenis wilayah merupakan dataran rendah dengan luas wilayah $8,72 \mathrm{Km}^{2}$ dan luas hutan $150 \mathrm{Km}$.

1 'Mangeloreng, Bantimurung, Maros - Wikipedia Bahasa Indonesia, Ensiklopedia Bebas' <https://id.wikipedia.org/wiki/Mangeloreng,_Bantimurung,_Maros> [accessed 22 April 2020].

2 'Profil Desa Desa Mangeloreng Kecamatan Bantimurung Kabupaten Maros Tahun 2019' (Maros, 2019), h. 1-6. 
Kondisi Demografis: Desa Mangeloreng memiliki 4 Dusun, Dusun Kaluku, Dusun Mangai, Dusun Lopi-Lopi, dan Dusun Bonto Padalle. Jumlah penduduk Desa Mangeloreng adalah 3.194 jiwa, terdiri dari laki-laki sebanyak 1.560 jiwa dan perempuan 1.634 jiwa, dengan jumlah Kepala Keluarga 837. Sebagian besar penduduk Mangeloreng adalah penduduk asli dan hanya sedikit yang merupakan pendatang. Sekitar $70 \%$ masyarakat bermata pencaharian sebagai buruh tani, baik pria maupun wanita. ${ }^{3}$

Berikut beberapa data Demografi Desa Mangeloreng tahun 2019 :

Data Penduduk:

$\frac{\text { Laki- Laki }}{\text { Perempuan }} \quad \frac{1642 \text { Jiwa }}{1688 \text { Jiwa }}$

Total Penduduk 3.330 Jiwa

Data Kepala Keluarga:

\begin{tabular}{ll} 
Jumlah Total KK Laki-Laki & $869 \mathrm{KK}$ \\
\hline Jumlah Total KK Perempuan & $\underline{125 \mathrm{KK}}$ \\
\hline Jumlah Total Keluarga_Miskin & $346 \mathrm{KK}$
\end{tabular}

Jumlah Penduduk Berdasarkan Struktur Usia:

\begin{tabular}{ll} 
0-1 Tahun & 35 Jiwa \\
\hline 1-4 Tahun & 184 Jiwa \\
\hline 5-14 Tahun & 613 Jiwa \\
\hline 15-39 Tahun & 1418 Jiwa \\
\hline 40-64 Tahun & 856 Jiwa \\
\hline 65 Tahun ke atas & 224 Jiwa \\
\hline
\end{tabular}

Kondisi Topografi: Desa Mangeloreng secara umum adalah lahan sawah tadah hujan, yang mempunyai potensi untuk pengembangan berbagai jenis tanaman padi, palawija dan tanaman holtikultura, ternak kecil maupun ternak besar dan pemeliharaan ikan air tawar. Desa Mangeloreng termasuk wilayah dataran rendah, berbukit atau sampai dengan elevasi 0 sampai 50 meter dari Permukaan Laut. Jenis tanah di wilayah kerja Desa Mangeloreng termasuk jenis tanah mediteran dan alovial dengan PH 5,5- 7 dan lahan sawah 5-6.

Berdasarkan Pada curah hujan di Desa Mangeloreng, Umumnya curah hujan tertinggi pada bulan Desember dan januari dan curah hujan terendah pada bulan Agustus dan September (sumber program BPP Bantimurung). Menurut pembagian Type iklim oldeman tergolong dalam kategori beriklim tropis type $\mathrm{C} 2$ dimana bulan basah 7-9 bulan dan bulan kering 2-3 bulan dengan temperature $20-30^{\circ} \mathrm{C}$.

3 'Gambaran Umum Desa Mangeloreng' <http://kampungkb. bkkbn.go.id/kampungkb /profile/4563> [accessed 22 April 2020]. 
Pembagian Penggunaan lahan wilayah mangeloreng di bagi sebagai berikut:

a. Areal Pemukiman: Tempat Pembangunan Rumah Masyarakat.

b. Areal Persawahan: Sawah tadah hujan / aliran irigasi.

\section{Profil Potensi Lokal:}

Kependudukan-Jumlah penduduk Desa Mangeloreng berdasarkan pekerjaanya dapat dirincikan sebagai berikut:

\begin{tabular}{ll} 
Jenis Pekerjaan & Jumlah Penduduk \\
Petani & 2020 Jiwa \\
\hline Nelayan & 0 Jiwa \\
\hline Buruh Tani / Buruh Nelayan & 0 Jiwa \\
\hline Buruh Pabrik & 190 Jiwa \\
\hline PNS & 15 Jiwa \\
\hline Pegawai Swasta & 310 Jiwa \\
\hline Wiraswasta/ pedagang & $\underline{115 \text { Jiwa }}$ \\
\hline TNI & 10 Jiwa \\
\hline Polri & 9 Jiwa \\
\hline Dokter & 1 Jiwa \\
\hline Bidan & 0 Jiwa \\
\hline Perawat & 1 Jiwa \\
\hline Jumlah Warga Penyandang Kebutuhan Khusus & 3 Jiwa
\end{tabular}

Bidang Sosial, Budaya dan Agama. ${ }^{4}$ Kondisi sosial pada masyarakat Desa Mangeloreng umumnya rukun dan damai nilai-nilai kerukunan dan persaudaraan dapat dilihat di masyarakat Desa Mangeloreng masyarakat berusaha menjunjung tinggi nilainilai tersebut. Di beberapa dusun atau bagian desa mangeloreng secara khusus masih perlu di bina persaudaraan dan kerukunanya karena masih terdapat beberapa warga tidak bisa berlapang dada menerima perbedaan pendapat dari masyarakat lainnya. Khususnya di dusun mangai bagian dalam, kasus perselisihan dua arah kiblat seharusnya dapat diselesaikan dengan sikap lapang dada menerima pendapat dari pihak Departemen agama dan tokoh agama setempat tapi pada kenyataannya masih ada warga yang fanatik terhadapa pendapat dan prinsipnya sehingga perselisihan dua arah kiblat belum dapat titik terang.

Budaya yang masih terus dijaga oleh masyarakat mangeloreng adalah budaya Barazanji dan Zikkiiri. Di setiap dusun terdapat kelompok-kelompok zikkiri dan barazanji yang terus beregenerasi. Perkembangan budaya ini begitu dijaga oleh masyarakat setempat dan diantara buktinya adalah adanya pengajaran zikkiri dan barazanji secara rutin dan intens kepada anak-anak. Ketika acara-acara perkawinan dan syukuran dilakukan oleh salah seorang masyarakat dapat dilihat bagaimana antusias mereka dalam

${ }^{4}$ Mahasiswa KKN STIBA Makassar, 'Kondisi Bidang Sosial, Budaya Dan Agama. Data Hasil Pengamatan Dan Interaksi Mahasiswa Di Lokasi KKN’ (Maros, 2020). 
meramaikan acara-acara tersebut, sehingga budaya berkumpul dan saling membantu antar masyarakat ketika ada acara masih sangat kuat.

Dalam bidang agama, Desa mangeloreng juga tidak ketinggalan dengan corak keharmonisan religi yang sangat baik. Budaya memuliakan para tokoh agama masih sangat kuat, imam desa, imam dusun dan imam masjid adalah sosok yang dituakan dalam kampung. Kegiatan-kegiatan yang berbasis agama islam juga masih lestari. Salah satunya adalah berdirinya Taman Pendidikan Al-Quran yang memiliki banyak santri, yaitu TPA Nurul Jannah dan TPA Nurul Karim Lopi-Lopi, total TPA resmi ada dua sedangkan TPQ / Rumahan ada sekitar 5 yang tersebar di setiap dusun. Tentunya kehadiran TPQ yang berlangsung dirumah warga ini berpotensi untuk bisa dijadikan sebagai TPA di masa yang akan datang.

Jumlah masjid di desa mangeloreng berjumlah 8 masjid, 1 gedung TPA dan 1 yayasan pendidikan islami. Remaja masjid yang aktif sekitar 3 unit dan majelis taklim sebanyak dua kelompok. Dari segi pendidikan agama masyarakat juga sangat antusias, hal tersebut dibuktikan dengan partisipasi masyarakat dalam kegiatan lomba santri TPQ antar dusun yang di adakan oleh mahasiswa. Secara demografis, kegiatan-kegiatan sosial keagamaan terhitung aktif di desa mangeloreng seperti adanya pertemuan majelis taklim, zikkiri, syukuran, khatmil quran dan pengajian.

Bidang Ekonomi. ${ }^{5}$ Masyarakat desa Mangeloreng sebagian besar bermata pencaharian petani karena lahan pertanian begitu luas, adapun selebihnya ada yang berprofesi sebagai peternak, guru, pedagang, dan pekerja pabrik. Desa mangeloreng adalah desa yang sedang berkembang dan masyarakat yang juga sedikit memiliki pencaharian variatif, hal ini disebabkan oleh faktor kesempatan kerja, apabila pada musim menunggu hasil tani sebagian masyarakat memilih bekerja sampingan seperti buruh bangunan, sopir mobil, dan usaha jualan pakaian dan barang campuran di pasar.

Bidang Pendidikan. ${ }^{6}$ Keadaan pendidikan masyarakat Desa Mangeloreng cukup baik karena sarana dan prasarana penunjang pendidikan sudah ada. Desa Mangeloreng memiliki 2 sekolah dasar negeri yaitu SD/Inpres 226 Lopi-Lopi dan SD/inpres 173 Mangai. Fasilitas di SD/Inpres 173 Mangai sudah terbilang lengkap begitupula jumlah tenaga pengajarnya. Berbeda dengan Sd/Inpres 226 Lopi-Lopi belum terdapat fasilitas seperti perpustakaan khusus dan sarana lainnya seperti alat-alat olahraga. Selain SD Desa mangeloreng juga memiliki satu buah yayasan pendidikan islami bernama Hidaytul Ihsan yang menampung siswa tingkat MI hingga MTS, meskipun fasilitas di yayasan tersebut belum sepenuhnya memadai tetapi bisa dikatakan sebagai lembaga yang terbilang cukup dan dalam tahap pengembangan.

Desa mangeloreng juga mempunyai taman kanak-kanak untuk anak usia krang lebih 5 tahun. TK tersebut terletak di dusun kaluku TK Pembina, dan juga TK PAUD

\footnotetext{
${ }^{5}$ Mahasiswa KKN STIBA Makassar, 'Kondisi Bidang Ekonomi. Data Hasil Pengamatan Dan Interaksi Mahasiswa Di Lokasi KKN' (Maros, 2020).

${ }^{6}$ Mahasiswa KKN STIBA Makassar, 'Kondisi Bidang Pendidikan. Data Hasil Pengamatan Dan Interaksi Mahasiswa Di Lokasi KKN’' (Maros, 2020).
} 
Lopi- Lopi di dusun Lopi-Lopi. Pada dasarnya pendidikan anak-anak di Desa mangeloreng sudah baik dan melek huruf. Masyarakatnya sudah sadar dengan Pendidikan. Terbukti dengan banyaknya anak-anak yang bersekolah di TK maupun SD.

Kesehatan, Lingkungan Hidup dan Pariwisata. ${ }^{7}$ Tingkat kesehatan di Desa Mangeloreng sudah terlihat cukup baik karena adanya petugas kesehatan dan kader posyandu yang secara rutin melakukan sosialisasi kesehatan. Kepedulian masyarakat tentang kesehatan juga sudah cukup baik, sebagian besar masyarakat sudah memenuhi kriteria jamban sehat meskipun masih ada sebagian yang belum memenuhi kriteria jamban sehat.

Masalah utama dalam bidang kesehatan di masyarakat Desa Mangeloreng adalah belum terselenggaranya kegiatan-kegiatan seperti penyuluhan tentang kesehatan dan lingkungan serta banyaknya warga yang membuang sampah sembarangan dan membuang sampah ke sungai. Tindakan tersebut dapat menyebabkan kualitas air menjadi menurun dan mengakibatkan banjir ketika air hujan deras. Di Desa Suka Mangeloreng juga terdapat potensi lokal yang bisa dijadikan menjadi tempat wisata. Di desa ini terdapat sebuah tebing dan gua-gua yang apabila dapat dikelola dengan baik berpotensi menjadi sebuah kawasan wisata.

Berdasarkan uraian profil Desa Mangeloreng di atas, maka pelaksanaan program kerja KKN STIBA Makassar angkatan III dinilai dapat memberikan kontribusi banyak bagi pengembangan kualitas SDM warga. Untuk itu ditetapkan tujuan pelaksanaan KKN sebagai berikut:

1. Untuk mengambil peran dalam membantu pemerintah melaksanakan program pembangunan Desa.

2. Untuk meningkatkan kesadaran sosial dan dakwah mahasiswa STIBA Makassar dalam berkontribusi pada peningkatan kapasitas SDM masyarakat Desa Mangeloreng.

3. STIBA Makassar sebagai perguruan tinggi keagamaan Islam berkewajiban dalam melaksanakan tri dharma perguruan tinggi pada pilar pengabdian masyarakat.

\section{METODE}

Sebelum itu juga, berdasarkan pemaknaan konteks profil Desa Mangeloreng, maka dalam pelaksanaan program kerja KKN terlebih dahulu dilakukan survei lapangan untuk keperluan analisis kebutuhan program pemberdayaan masyarakat. Dengan mengaplikasikan instrumen sederhana dalam memetakan kebutuhan tersebut, maka kemudian dilakukan analisis SOAR secara ringkas sebagai berikut:

1. Strenght: masyarakatdan kondisi Desa Mangeloreng:

${ }^{7}$ Mahasiswa KKN STIBA Makassar, 'Kondisi Kesehatan, Lingkungan Hidup Dan Pariwisata. Data Hasil Pengamatan Dan Interaksi Mahasiswa Di Lokasi KKN' (Maros, 2020). 
a. Berkarakter religius, masih mempertahankan tradisi zikkiri', dan sangat menokohkan tokoh Agama dalam pengambilan kebijakan Desa.

b. Tampak banyak remaja dan anak usia dini.

c. Terdapat Taman Pendidikan Qurani mandiri/ rumahan di setiap dusun.

d. Luasnya Lahan untuk pembangunan dan pemberdayaan desa

2. Oppurtunities: masyarakat dan kondisi Desa Mangeloreng:

a. Banyak Penyuluh Agama Kecamatan.

b. Keberadaan Lembaga Sosial dan Lembaga Dakwah.

c. Peluang beasiswa dan sekolah gratis mumpuni.

d. Kemudahan akses informasi dan transportasi.

e. Dukungan pemerintah setempat.

3. Aspiration: masyarakat dan kondisi Desa Mangeloreng:

a. Remaja masjid kurang pembinaan, maka perlu dibina dan dimotivasi.

b. Perlu dilakukan upaya pembinaan santri secara intensif dan terprogram dengan baik.

c. Perlu diupayakan pembinaan qurani bagi orang dewasa.

4. Result: masyarakat dan kondisi Desa Mangeloreng:

a. Terciptanya generasi yang berpendidikan dan berkarakter.

b. Terciptanya kader dan generasi yang qurani dengan berdirinya TPA di setiap dusun.

c. Terciptanya masyarakat qurani dan berakhlak Islami.

Berdasarkan hasil ringkasan analisis SOAR di atas, maka ditetapkan program kerja KKN STIBA Makassar angkatan III di Desa Mangeloreng yaitu sosialisasi dan silaturahim (SS), pembinaan TK/TPA, peresmian TK/TPA, pengajaran SD/SMP, kelompok belajar bahasa arab (KBBA), festival santri (FS), dan pembelajaran dirosa (PD). Program-program tersebut dinilai adaptif struktur di masyarakat dan dapat berkontribusi dalam peingkatan SDM di Desa Mangeloreng.

Hasil-Hasil pengabdian masyarakat (PkM) telah banyak dilakukan oleh pelaksana $\mathrm{PkM}$ dan dijumpai banyak artikel berkenaan dengannya. Berikut beberapa artikel PkM terdahulu dan relevan dengan PkM berwujud KKN ini:

1. PkM yang dilakukan oleh Sholeh \& Basuki menyoal tentang sosialisasi internet sehat bagi remaja masjid Aqrob Wojo Kab. Bantul, menemukan bahwa mayoritas remaja sudah familiar dengan akses internet dan yang diakses adalah media sosial dan postingan bergenre remaja. Adapun hasil sosialisasi diekpektasikan agar para peserta dapat memahami dan menyikapi bagaimana berinternet secara sehat dan aman serta memahami bahaya bahaya selama berinteraksi melalui media internet. ${ }^{8}$

${ }^{8}$ Muhammad Sholeh and Untung Joko Basuki, 'Implementasi Program Kuliah Kerja Nyata Melalui Sosialisasi Internet Sehat Bagi Remaja Masjid Aqrob Nganjar,Wojo Kabupaten Bantul', Adimas : Jurnal Pengabdian Kepada Masyarakat, 2019.h.23-31. 
2. PkM yang dilakukan oleh Aliyyah, dkk., tentang penyuluhan lingkungan sehat sebagai program kerja KKN dengan hasil yang telah mencapai sasaran kerja yaitu di antaranya tersedianya bak sampah di beberapa titik di Desa Cipayung Girang, perilaku masyarakat terhadap pengelolaan sampah. ${ }^{9}$

3. PkM yang dilakukan oleh Kartini, dkk., tentang pelatihan menganyam rotan sebagai bagian dari kegiatan pengabdian masyarakat dengan hasil yang memberikan dampak positif kepada masyarakat yaitu menambah banyak pengetahuan, keterampilan dan pengalaman dari kelompok masyarakat. ${ }^{10}$

4. PkM yang dilakukan oleh Divayana, dkk., dalam mana memfokus pada pemberdayaan masyarakat dengan hasil kegiatan KKN-PPM yang menunjukkan adanya keberhasilan seluruh komponen masyarakat Desa Belatungan dalam memahami materi dan menerapkan beberapa program yang menjadi terobosan pemenuhan kebutuhan vital masyarakat dalam bidang ekonomi kerakyatan, bidang pendidikan, sosial, dan seni, bidang teknologi informasi, serta bidang sanitasi dan kesehatan. ${ }^{11}$

5. Penelitian yang dilakukan oleh Perdana, dkk., yang menelaah tentang pengaruh KKN terhadap tingkat keterampilan sosial mahasiswa, menyimpulkan bahwa semakin tinggi tingkat interaksi yang terjadi selama KKN akan mempengaruhi keterampilan sosial pada mahasiswa. ${ }^{12}$

Atas paparan hasil PkM atau penelitian di atas, maka persamaan pada orientasi KKN STIBA Makassar ini adalah terletak pada upaya pelaksanaan program kerja yang manfaatnya dapat dirasakan langsung oleh masyarakat, sembari melatih keterampilan dan kecerdasan sosial, emosional, dan empati mahasiswa.

Namun, kekhasan dari pengabdian masyarakat yang dilakukan oleh mahasiswa STIBA Makassar adalah terletak pada peningkatan baca tulis al-Qur'an, pengetahuan dan wawasan keislaman serta pembinaan akhlak masyarakat. Orientasinya diarahkan pada berbagai bidang seperti pendidikan, sosial keagamaan, dan kesehatan.

${ }^{9}$ Rusi Rusmiati Aliyyah, R ST Pupu Fauziah, and Nur Asiyah, 'Peningkatan Cinta Lingkungan Dan Pemberdayaan Masyarakat Pedesaan Melalui Program Pengabdian Masyarakat', Qardhul Hasan: Media Pengabdian Kepada Masyarakat, 3.1 (2018), h.46.

${ }^{10}$ Nurul Hikmah Kartini and others, 'Kerajinan Tikar Purun Di Kelompok Masyarakat Pimpinan Daerah Aisyiyah Kuala Pembuang Seruyan', PengabdianMu: Jurnal Ilmiah Pengabdian Kepada Masyarakat, 4.1 (2019), h.46-49.

${ }^{11}$ Dewa Gede Hendra Divayana, I Putu Wisna Ariawan, and P. Wayan Arta Suyasa, 'Pelaksanaan Kkn-Ppm Dalam Rangka Pemberdayaan Masyarakat Demi Mewujudkan Swadaya Pemenuhan Kebutuhan Vital Berlandaskan Semangat Ngayah', Widya Laksana, 8.2 (2019), h.161 .

12 Amelia Perdana, M.Si Drs. Holilulloh, M.Si Drs. Holilulloh, and S.Pd, M.Pd Yunisca Nurmalisa, Pengaruh Pelaksanaan Kuliah Kerja Nyata Terhadap Keterampilan Sosial Mahasiswa Program Studi Ppkn, 25 July 2013, I. 


\section{PEMBAHASAN}

\section{Sosialisasi dan Silaturahmi (SS)}

Tujuan: program ini berarah tujuan untuk memperkenalkan tim mahasiswa KKN angkatan III STIBA Makassar dan mempererat jalinan silaturahmi dengan masyarakat sekitar Mangeloreng. Berkenaan silaturahmi, melalui penelitian Darussalam yang mengkaji sekumpulan hadi-hadis Nabi silaturahmi berhasil menyimpulkan bahwa silaturrahmi merupakan interaksi sosial yang mempunyai banyak manfaat bagi manusia demi untuk mewujudkan kebahagiaan di dunia dan di akhirat. Oleh karena itu, Rasulullah sangat menekankan pentingnya silaturrahmi dan larangan memutuskannya. ${ }^{13}$

Kegiatan ini diawali dengan bersosialisasi dan bersilaturahmi ke setiap rumahrumah warga yang berada di Desa Mangeloreng. Kegiatan ini dilaksanakan pada awal masa KKN agar para warga mengetahui keberadaan mahasiswa KKN, karena kegiatan ini di anggap penting maka para mahasiswa membuat jadwal di setiap sorenya dengan menyapa warga dan bersilaturahmi.

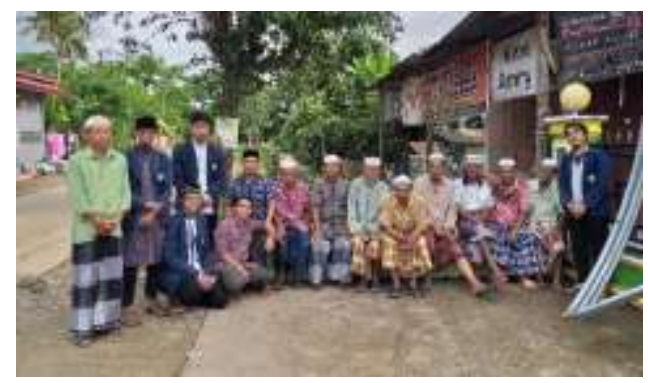

Gambar 1.2. Sosialisasi dan Silaturahmi

Para mahasiswa menyebar di setiap dusun dan menyapa warga setempat yang sedang bertani atau yang sedang bersantai di rumah-rumah mereka. Adapun kendala yang dirasakan mahasiswa adalah kurangnya percakapan antara sebagian mahasiswa dan warga, mahasiswa enggan atau masih malu menegur warga terlebih dahulu. Pengalaman menarik yang didapatkan adalah ketika senyum dibalas senyum dan bisa mengenal banyak warga desa dengan sangat baik, serta mendapatkan dukungan moril dari Kepala Desa Mangeloreng dan tokoh-tokoh masyarakat yang membuat mahasiswa tetap semangat dalam menjalankan kegiatan ini hingga akhir masa KKN.

Hasil kegiatan: setelah berjalannya beberapa waktu, warga di Desa Mangeloreng sudah sangat mengenal mahasiswa KKN yang berada di desa tersebut, yang dimana pada awalnya mereka enggan atau malu menegur terlebih dahulu, kini mulai menyapa, selain dari pada itu, warga Desa Mangeloreng juga tidak segan-segan memberikan beras, telur, sayur dan lain sebagainya untuk para mahasiswa, dan sebelum berakhirnya masa KKN para masyarakat sangat bersedih serta menginginkan masa KKN para mahasiswa untuk diperpanjang karena mereka mulai simpati terhadap mahasiswa.

${ }^{13}$ A. Darussalam, 'Wawasan Hadis Tentang Silaturahmi A.', Jurnal Kajian Ilmu Hadis, 8.2 (2017), h. 116. 
Keberlanjutan Program: tentu saja para mahasiswa KKN STIBA Makassar di Desa Mangeloreng menindak lanjuti program sosialisasi dan silaturahmi ini, dengan cara para mahasiswa akan sesekali mengunjungi desa tersebut untuk bersilaturahmi kepada masyarakat, selain dari pada itu, sebagian mahasiswa pun sudah mengambil nomornomor handphone warga atau para tokoh masyarakat agar bisa selalu berkomunikasi dan bersilaturahmi kepada mereka.

\section{Pembinaan TK/TPA}

Tujuan: pembinaan TK/TPA bertujuan untuk mengajarkan al-Qur'an sesuai kaidah tajwid serta mengajarkan untuk mencintai al-Qur'an. Perihal Pembinaan TPA, berdasarkan simpulan penelitian Abdurrohman menyatakan bahwa faktor keberhasilan yang menentukan efektivitas pembelajaran di TPA dalam meningkatkan kemampuan membaca al-Qur'an santri ialah terletak pada kemampuan pengajarnya dalam mengefektifkan sistem assistensi dan kontrol yang baik pada pengajaran iqra' sehingga hasil membaca al-Qur'an santri mendapatkan hasil yang baik. ${ }^{14}$

Kegiatan ini diawali dengan sosialisasi mahasiswa terhadap guru-guru TK/TPA dan anak-anak yang ada di Desa Mangeloreng, dengan cara mengajar mengaji anak-anak di setiap masjid yang ada di desa tersebut. Dengan metode iqra', tahsin, menghafal, dan dirosa untuk anak-anak di setiap dusun di Desa Mangeloreng. Sebelum mengaji para mahasiswa mengumpulkan santri dalam satu komando, kemudian satu dari mahasiswa memberikan arahan kepada santri seperti memberikan yel-yel, membaca doa dan memberikan sedikit nasehat kepada santri. Kemudian setelah itu para santri dibentuk beberapa halakah dan setiap halakah ditangani oleh satu orang mahasiswa. Kemudian para mahasiswa diberikan jadwal mengajar di setiap masjid pada waktu zuhur dan asar di setiap dusun di Desa Mangeloreng.

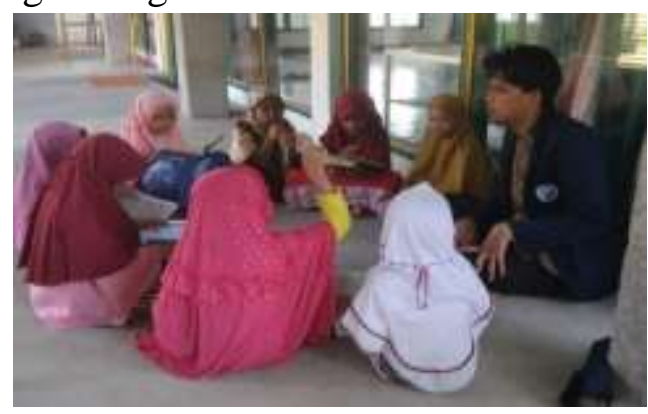

Gambar 1.3. Proses pengajaran TPA

Pengalaman menarik yang dirasakan mahasiswa adalah ketika mahasiswa kesulitan mengatur santri yang kecil-kecil sehingga mahasiswa harus kejar-kejaran dengan santri ketika dalam proses mengajar, dan sebagian besar santri susah diatur sehingga mahasiswa harus sabar dalam menahan emosinya ketika berhadapan dengan santri. Adapun faktor pendukung dalam kegiatan ini adalah keterbukaan pengurus masjid

14 Pendidikan Al-qur An and others, Efektivitas Program Pembelajaran Taman Efektivitas Program Pembelajaran Taman Pendidikan Al-Qur ' an ( Tpa) Dalam Meningkatkan Kemampuan Membaca Al-Qur ' an Di Tpa Al-Hikmah, 2017. 
dan guru-guru TK/TPA yang memberikan kesempatan kepada mahasiswa untuk mengajar anak-anak mengaji, dan masyarakat sangat merespon baik kegiatan tersebut.

Kendala yang juga dirasakan adalah kurangnya buku iqra' dan buku dirosa bagi anak-anak sehingga mahasiswa kesulitan mengajar dikarenakan buku tersebut digilir disetiap dusun yang berada di Desa Mangeloreng, dan kurangnya alat-alat bantu untuk mengajar sehingga mahasiswa hanya menggunakan peralatan seadanya. Banyaknya anak-anak juga menjadi sebuah kesulitan bagi mahasiswa yang jumlahnya hanya sedikit dalam mengatur anak-anak.

Hasil Kegiatan: perubahan yang terjadi pada masyarakat Desa Mangeloreng tampak tatkala mahasiswa mengajarkan al-Qur'an kepada anak-anak santri yang sudah semakin pintar membedakan huruf dalam al-Qur'an dan sebagian dari mereka ada yang sudah lancar mengaji dan ada juga yang sudah mulai menghafal. Adapun gambaran masyarakat sebelum datangnya mahasiswa KKN adalah banyaknya anak-anak yang tidak tahu mengaji. Bahkan di antara mereka ada yg tidak tahu sama sekali dalam penyebutan huruf yang baik, karena kebanyakan dari mereka belajar mengaji sama orang tua dulu. Ditemukan penyebutan hurufnya jauh berbeda dengan apa yang diajarkan mahasiswa KKN STIBA Makassar, dan kebanyakan di antara mereka juga baru merasakan yang namanya belajar mangaji.

Keberlanjutan Program: keberlanjutan program ini sebaiknya dilanjutkan oleh remaja masjid disetiap dusun yang ada di desa Mangeloreng atau orangtua santri yang sudah bagus dalam bacaan alqurannya, agar anak-anak tetap belajar mengaji meskipun para mahasiswa sudah kembali kekampus mereka.

\section{Peresmian TK/TPA}

Tujuan: perermian TK/TPA bertujuan untuk membantu Desa Mangeloreng untuk meningkatkan jumlah TK/TPA di desa tersebut. Menurut Albab, dkk., peresmian TPA berfungsi untuk mengingatkan masyarakat akan pentingnya pembelajaran atau pengetahuan tentang keagamaan dan meningkatkan semangat belajar anak tentang keagamaan. ${ }^{15}$

Kegiatan ini merupakan program tambahan karena dianggap sangat penting untuk dilaksanakan karena melihat hanya terdapat satu TK/TPA yang resmi di Desa Mangeloreng, maka diadakan peresmian atau membuka satu TK/TPA di Dusun LopiLopi. Kegiatan ini diawali dengan mengumpulkan anak-anak yang berada di dusun tersebut dan kemudian mencari pengajar untuk mereka dari kalangan masyarakat sekitar dusun tersebut. Tujuannya untuk menindaklanjuti proses belajar mengajar setelah kepergian mahasiswa KKN, dan kemudian melakukan sosialisasi ke kantor-kantor yang berkaitan dengan pengesahan pengadministrasian TK/TPA tersebut dan kepada Imam Desa Mangeloreng.

${ }^{15}$ Muhammad Ulil Albab and others, 'Pembentukan Taman Pendidikan Al-Qur' an ( TPA ) Untuk Mencetak Generasi Qur’ Ani’, 1 (2019), h.29-31. 
Hasil Kegiatan: begitu banyak perubahan yang terjadi terhadap anak-anak sekitar dusun tersebut setelah dibentuknya TK/TPA, yang dulunya anak-anak hanya mengaji di rumah-rumah mereka atau hanya mengaji kampung, kini mereka bisa mengaji bersama di masjid dengan metode pembelajaran menggunakan IQRA' serta menanamkan sedikit materi-materi tentang dasar-dasar ilmu Islam, adab dan akhlak. Masyarakat sekitar sangat berterima kasih terhadap mahasiswa yang sudah membantu dalam peresmian TK/TPA ini yang membuat anak-anak mereka semakin rajin untuk pergi ke masjid dan semakin paham akan ilmu-ilmu Islam.

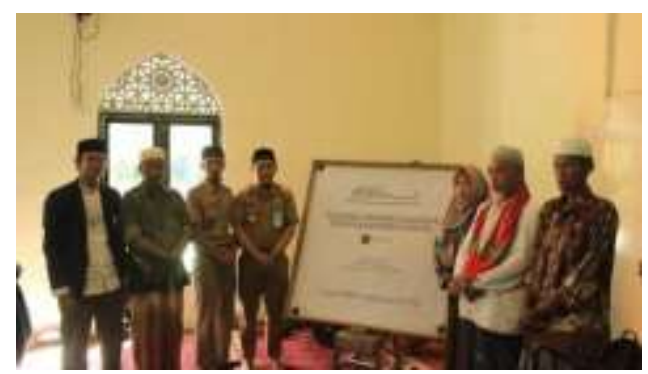

Gambar 1.4. Peresmian TK/TPA.

Keberlanjutan Program: setelah usai kegiatan peresmian ini, para mahasiswa menindaklanjutinya dengan proses belajar mengajar terhadap anak-anak santri TPA Nurul Karim, dan kemudian dilanjutkan oleh guru-guru mereka yang telah dibentuk setelah kepergian mahasiswa KKN STIBA Makassar angkatan III.

\section{Pengajaran di SD/SMP}

Tujuan: pengajaran SD/SMP bertujuan untuk mengajarkan agama Islam kepada para peserta didik. Berdasarkan penelitian Ismail, Hasan \& Musdalifah menunjukkan bahwa proses magang pengajaran di sekolah mampu meningkatkan softskill mahasiswa meliputi keterampilan berkomunikasi, keterampilan beradaptasi dalam pekerjaan, keterampilan mengelola kerja tim, keterampilan bersosialisasi, serta ketelitian dalam bekerja. Dengan demikian, kegiatan pengajaran SD/SMP berdaya simbiosis mutualisme bagi peserta didik maupun mahasiswa KKN. ${ }^{16}$

Kegiatan ini diawali dengan sosialisasi antara Mahasiswa dengan beberapa sekolah yang berada di Desa Mangeloreng, khususnya pada 3 (tiga) sekolah. Sekolah SD 226 Inpres tepatnya di Dusun Lopi-Lopi, Sekolah Yayasan Hidayatul Ihsan tepatnya di Dusun Bontopadalle dan sekolah SD 173 Inpres tepatnya di Dusun Mangai. Para mahasiswa menyebar untuk mendatangi sekolah-sekolah yang ada di Desa Mangeloreng untuk meminta izin kepada kepala sekolah agar bisa mengajar di sekolah tersebut.

Alhamdulillah, di setiap sekolah mahasiswa diterima dengan baik dan menerima mahasiswa untuk mengajar di setiap sekolah yang berada di Desa Mangeloreng. Adapun kendala yang dihadapi mahasiswa ialah kurangnya materi untuk mengajar dan seringnya terlambat datang ke sekolah. Pengalaman menarik yang baru pertama kali menjadi

16 Ismail Ismail, Hasan Hasan, and Musdalifah Musdalifah, 'Pengembangan Kompetensi Mahasiswa Melalui Efektivitas Program Magang Kependidikan', Edumaspul - Jurnal Pendidikan, 2.1 (2018), h. 124. 
pengajar adalah indahnya bermain bersama para siswa sehingga kelas tidak menjadi bosan, serta dengan tersedianya papan tulis, spidol, buku-buku pelajaran, dan lain sebagainya, yang bisa mendukung atau membantu mahasiswa mengajar di sekolah.

Hasil Kegiatan: program belajar mengajar di SD/SMP berjalan dengan lancar. Para siswa Sekolah Dasar yang dulunya tidak mengetahui rukun iman dan lain-lain, kini sudah mulai diketahuinya, oleh karena mahasiswa mengajarkannya dan mengajarkan ilmu-ilmu dasar Islam lainnya. Tidak lupa pula para mahasiswa mengajarkan sedikit dasar- dasar bahasa Arab dan pelajaran akidah untuk siswa SMP yang berada di Yayasan Hidayatul Ihsan. Alhamdulillah, banyak dari siswa telah mendapatkan pengalaman atau ilmu Islam dan bahasa Arab dalam mana mereka belum pernah pelajari sebelumnya.

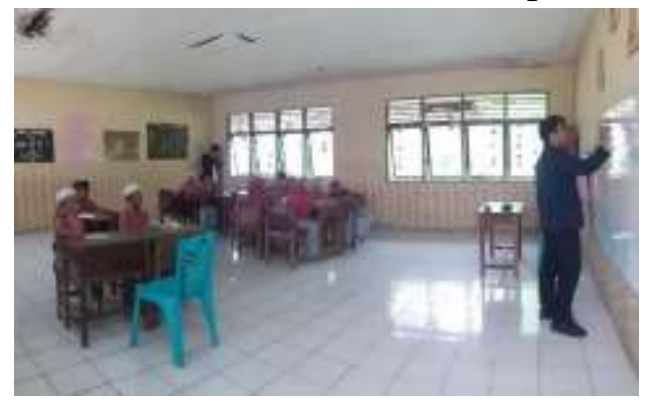

Gambar 1.5. Pengajaran di SD

Keberlanjutan Program: setelah usainya program mengajar di SD/SMP, maka para mahasiswa mengingatkan kepada para siswa untuk selalu belajar ilmu agama dan bahasa Arab sebagai bekal di kemudian hari. Selain dari pada itu, maka para gurulah yang menindaklanjuti program mengajar di SD/SMP khususnya di bidang Ilmu agama dan bahasa Arab.

\section{Kelompok Belajar Bahasa Arab (KBBA)}

Tujuan: kegiatan KBBA ini bertujuan untuk memperkenalkan bahasa Arab dan menumbuhkan kecintaan terhadapnya. Berdasarkan simpulan penelitian Wulandari menyatakan bahwa salah satu faktor problem pembelajaran bahasa Arab bagi anak usia 7 sampai 13 tahun adalah dukungan keluarga dan wadah tempat pengembangan bahasa Arab itu sendiri. Dengan demikian, pembentukan komunitas atau KBBA dinilai dapat dijadikan sebagai wadah pengembangan minat belajar bahasa Arab bagi anak-anak atau santri di Desa Mangeloreng. ${ }^{17}$

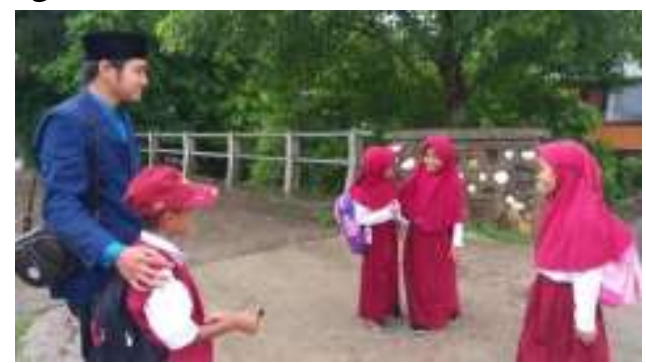

Gambar 1.6. Praktik Kosa Kata Bahasa Arab

${ }^{17}$ Iain Surakarta, 'Problematika Pebelajar Bahasa Arab Anak Usia 7 Sampai 13 Tahun Marlina Wulandari Iain Surakarta’, 2008, 2019,h. 559. 
Kegiatan ini diawali dengan melakukan sosialisasi terhadap anak-anak SD/SMP dimana mahasiswa yang bertemu dengan anak SD/SMP langsung diajarin bahasa Arab entah itu di jalan atau di rumah-rumah mereka. Sebagian mahasiswa juga mengajarkan bahasa Arab di sekolah-sekolah yang mana pada sekolah itu tidak ada pelajaran bahasa arabnya. SD 226 Inpres Lopi-Lopi misalnya, di sekolah ini tidak diajarkan bahasa Arab dikarenakan tidak adanya guru di bidang bahasa Arab, maka mahasiswa KKN diminta menjadi guru bahasa Arab di sekolah selama masa KKN. Pengalaman menarik belajar bahasa Arab dengan menggunakan metode nyanyian menjadikan anak-anak tidak bosan. Adapun kendala yang dihadapi ialah susahnya mengajak anak-anak untuk belajar bahasa Arab di karenakan asyik bermain game online di-handphone mereka.

Hasil Kegiatan: Alhamdulillah, program kelompok belajar bahasa Arab menjadi salah satu daya tarik bagi anak-anak, dalam mana anak-anak di Desa Mangeloreng sangat menyukai pelajaran bahasa Arab sehingga mereka sudah mengetahui dasar-dasar dari bahasa Arab. Contohnya seperti nama-nama benda, nama hewan, dhomir, dan lain sebagainya. Mereka juga pandai menghitung 1 sampai 10 dalam bahasa Arab, selain dari pada itu, mereka juga pandai memperkenalkan diri dengan menggunakan bahasa Arab walau masih terbata bata.

Keberlanjutan Program: tindak lanjut yang dicanangkan oleh mahasiswa ialah menasihati siswa agar selalu belajar bahasa Arab dan para guru yang akan menindaklanjuti pembelajaran bahasa Arab di sekolah-sekolah.

\section{Festival Santri (FS)}

Tujuan: kegiatan FS bertujuan untuk meningkatkan semangat santri dalam mempelajari agama Islam serta membantu mewujudkan generasi saleh dan salehah. Menurut hasil pengabdian masyarakat yang dilakukan oleh Anggraeni ihwal festival anak saleh menyatakan bahwa kegiatan tersebut bermanfaat untuk memberikan pengalaman baru bagi warga, khususnya anak-anak untuk terus berusaha berlomba-lomba dalam kebaikan. ${ }^{18}$

Kegiatan FS adalah kegiatan yang berisi lomba-lomba Islami dan outdoor yang dilaksanakan oleh mahasiswa KKN STIBA Makassar Angkatan III kurang lebih selama 4-5 hari di pekan ke 5 masa KKN di Desa Mangeloreng. Kegiatan yang bertemakan "Menumbuhkan Pribadi yang Berakhlaq Qurani Di Zaman Milenial" ini bertujuan sebagai media untuk memperkokoh silaturrahim antar dusun dalam upaya menopang ukhuwah Islamiyah dan menumbuhkan rasa cinta anak terhadap al-Qur'an serta menumbuhkan rasa sportifitas. Kegiatan ini juga bertujuan sebagai sarana untuk menumbuhkan semangat kebersamaan di setiap jenjang perlombaan.

Terakhir, kegiatan ini juga sebagai media evaluasi kualitas santri TK/TPA Tingkat Dusun Desa Mangeloreng yang selanjutnya akan menjadi bahan follow up perbaikan

${ }^{18}$ Universitas Ahmad, Dahlan Yogyakarta, and A Pendahuluan, 'Perlombaan Festival Anak Sholeh Masjid Al- Hidayah Sebagai Upaya Untuk Menumbuhkan Kreativitas Dan Meningkatkan Partisipasi Warga Perumahan Perwita Regency', 1.2 (2017), h.117. 
kurikulum termasuk proses pembelajaran. Dalam melaksanakan kegiatan ini, mahasiswa(i) memulainya dengan sosialisasi di setiap dusun-dusun setelah salat berjemaah di waktu salat. Musyawarah dan rapat koordinasi mahasiswa(i) dilakukan secara intens untuk mempersiapkan kegiatan.

Dana kegiatan ini diperoleh dari proposal dan broadcast donasi yang disebar oleh panitia beberapa pekan sebelum waktu Pelaksanaan. Segala kebutuhan seperti piagam, piala, bingkisan dan keperluan lainya sudah mulai disiapkan satu pekan sebelumnya. Pada saat pelaksanaan, Kegiatan dilaksanakan selama 5 hari yang diawali dengan pembukaan dan lomba di setiap dusun, Bontopadalle, Mangai, Lopi-Lopi dan Kaluku.

Final Kegiatan ini dilaksanakan di Masjid Al-Musafir Soddang Jaya, yang diikuti oleh masing-masing perwakilan dari juara-juara dusun. Peserta dari kegiatan ini mencapai kurang lebih 200 orang, dengan cabang perlombaan seperti azan, tilawah, pildacil, MTQ, MHQ, tarik tambang, masukkan paku ke botol, dan tebak gaya.

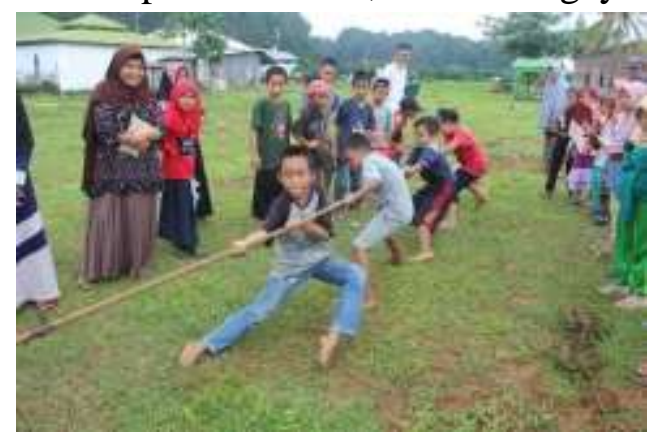

Gambar 1.7. Kegiatan Tarik Tambang Santri

Pengalaman yang menarik dari kegiatan ini adalah ketika melaksanakan lomba outdoor seperti tarik tambang dan tebak gaya, lomba ini sangat diminati banyak anakanak yang membuat mahasiswa kebingungan bagaimana cara mengatur dan menentukan pemenangnya apalagi jika umur dan postur tubuh mereka berbeda-beda. Anak-anak antar dusun saling bermusuhan dengan adanya pengaturan yang tidak maksimal oleh panitia KKN, saat itulah mahasiswa berusaha untuk membuat mereka untuk tidak saling bermusuhan dan fokus untuk lomba dan menyampaikan pentingnya untuk saling silaturahmi antar sesama anak-anak di Desa Mangeloreng dan tidak boleh berpecah belah hanya karena perlombaan.

Kegiatan lomba anak saleh antar dusun baru pertama kali diadakan. Kegiatan ini mengajarkan bagaimana bersabar ketika menghadapi dan mengurus anak-anak. Sebagai seorang pembina dari mereka, seharusnya kita berusaha memahamkan kepada mereka untuk berlomba bukan untuk sekedar hadiah tetapi untuk saling mengenal di antara mereka dan memotivasi untuk banyak belajar dan senantiasa menjaga sportifitas. Bagi mahasiswa KKN, dari kegiatan ini memberikan pelajaran, pentingnya kekompakan dan persiapan yang lebih matang untuk kegiatan yang melibatkan banyak anak-anak seperti ini. 


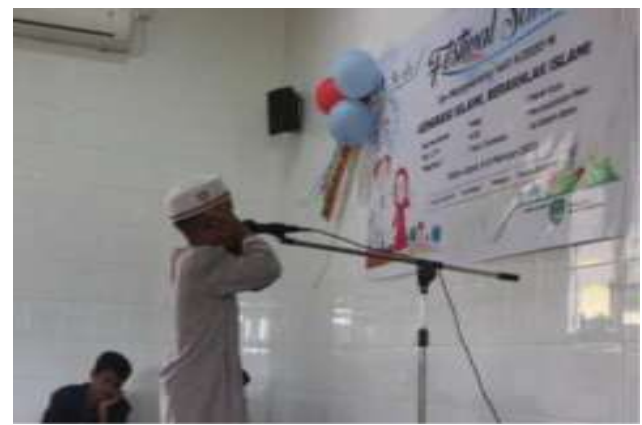

Gambar 1.8. Kegiatan Lomba Azan

Faktor pendukung kegiatan ini adalah dukungan dari pemerintah setempat mulai dari pengurus masjid, pembina TPA, kepala dusun dan kepala desa. Perlengkapan yang memadai dan tempat perlombaan juga menjadi faktor pendukung dilaksanakannya kegiatan ini dengan baik. Begitu pula tim dekorasi dari akhawat dan tim juri dari panitia, dan dukungan dari masyarakat setempat turut memotivasi mahasiswa sebagai panitia dalam melaksanakan kegiatan ini dengan sebaik-baiknya.

Kendala dalam kegiatan ini yaitu masih minimnya SDM dari mahasiswa untuk mengatur dan melaksanakan kegiatan secara profesional. Kurangnya komunikasi yang baik antar mahasiswa sehingga kadang terjadi masalah teknis saat perlombaan berlangsung. Kegiatan ini juga terkendala pada kurangnya TOA atau pengeras suara yang digunakan untuk pengarahan, konsumsi panitia dan peserta lomba tidak diadakan, lembar penilaian para juri juga masih kurang, waktu perlombaan kadang tidak tepat waktu, dan terlambatnya sertifikat peserta lomba.

Solusi dari kendala yang dihadapi adalah musyawarah dan komunikasi yang baik sehingga pengaturan, pengontrolan begitupula komunikasi dengan akhawat (mahasiswi) dapat kembali disesuaikan. Untuk pengadaan TOA, mic masjid dan sound system sekolah menjadi solusi, juga kertas-kertas kosong untuk lembar penilaian juri dan data. Terkait sertifikat ini, tetap diadakan bagi yang belum mendapatkan dan dibagi sebelum penarikan KKN.

Hasil Kegiatan: perubahan yang terjadi di masyarakat, sebelum mengikuti kegiatan KKN yakni festival santri, motivasi masyarakat untuk membimbing dan membina anak-anak mereka untuk belajar agama yang dinilai masih kurang. Komunikasi sesama orang tua anak-anak terkadang masih renggang, kerjasama antara jemaah masjid dan pengurus masjid juga masih kaku, dan banyak orang tua yg tidak tahu potensi anakanak mereka. 


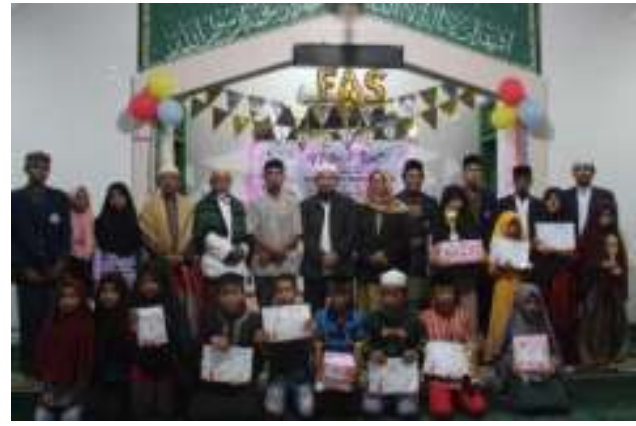

Gambar 1.9. Foto Bareng Pemenag FS

Setelah kegiatan ini, Alhamdulillah, setidaknya mahasiswa KKN sedikit memberikan warna baru dengan dilaksanakannya kegiatan ini. Hal itu dikarenakan banyak orang tua yang hadir menyaksikan lomba anaknya, mempererat silaturahim antar masyarakat, juga terhadap mahasiswa KKN, menyadari potensi yang dimiliki oleh anakanak mereka. Begitupula para anak-anak generasi desa menjadi termotivasi untuk terus belajar dan bersemangat dalam menuntut ilmu Agama. Mahasiswa KKN setelah kegiatan ini tanpa disadari telah memberikan sumbangsih pemikiran dan kesadaran kepada masyarakat dan kepada anak-anak sebagai kader bangsa ke depan.

\section{Pembelajaran Dirosa (PD)}

Tujuan: kegiatan PD bertujuan agar mendekatkan warga kepada al-Qur'an serta memperbaiki bacaan al-Qur'an warga. Hal ini didukung oleh penelitian yang dilakukan oleh Saddang yang menunjukkan bahwa dari 67 peserta yang telah mengikuti pembelajaran al-Qur'ān dengan menggunakan metode Dirosa yang dilaksanakan sebanyak 20 kali pertemuan tampak sudah mampu membaca al-Qur'ān dengan baik dan lancar meski sebelum mengikuti metode Dirosa, 34 peserta pada kategori buta huruf, 27 peserta yang membaca al-Qur'ān dengan terbata-bata, dan 6 orang pada kategori lancar tetapi masih ada kesalahan tajwid. ${ }^{19}$

Kegiatan ini diawali dengan melakukan sosialisasi kepada masyarakat di setiap masjid yang ada di Desa Mangeloreng. Aksinya dengan meperkenalkan metode simpel belajar al-Qur'an bagi orang dewasa yang tidak memiliki banyak waktu luang untuk belajar al-Qur'an. Kemudian dilakukan pemasangan spanduk pemberitahuan bagi masyarakat yang dipasang didepan masjid. Kemudian setelah melakukan sosialisasi, mahasiswa diberi tugas dan tanggung jawab di setiap masjid yang telah ditentukan sebagai pengajar untuk membuka halakah dirosa kepada jemaah yang ingin ikut belajar.

Adapun kendala dalam kegiatan ini kurangnya ketepatan waktu antara Mahasiswa dan masyarakat yang mau belajar, sebab di Desa Mangeloreng adalah mayoritas petani yang sibuk bekerja di waktu pagi-sore.

${ }^{19}$ Muhammad Saddang, 'Implementasi Metode Dirosa Dalam Pembelajaran Al-Qur'ān Dewan Pimpinan Daerah Wahdah Islamiyah Makassar’, 2018. 


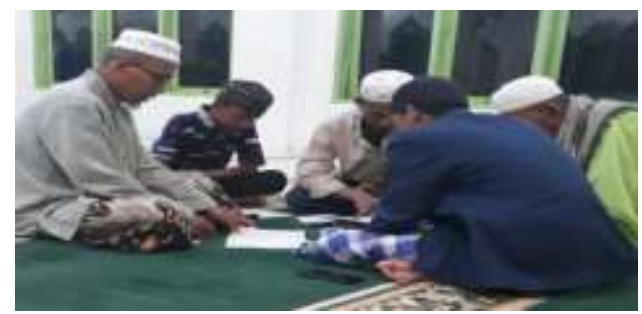

Gambar 1.10. Proses Pembelajaran al-Qur'an Metode Dirosa

Hasil Kegiatan: kegiatan Belajar al-Qur'an dengan metode dirosa ini berjalan lancar, masyarakat yang dulunya masih terbata-bata dalam membaca, kini sudah memperoleh perubahan bacaan yang signifikan. Mulai dari penyebutan makhraj huruf, tajwid dan lain-lain mulai dipahami. Namun, ada beberapa hal penting, yaitu saat pengajaran berlangsung, banyak di antara jemaah yang berbaring saat halakah belajar tengah berjalan. Sebab kebanyakan masyarakat yang ikut adalah lansia, dan mereka tidak tahan duduk bersilah dalam waktu yang cukup lama.

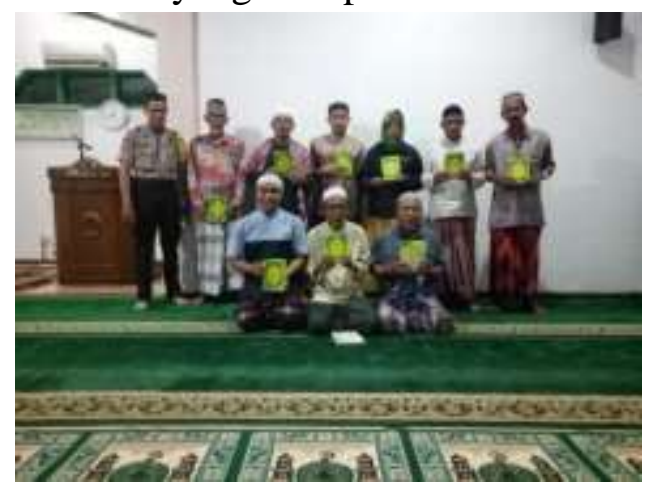

Gambar 2.1. Foto Bersama Di Akhir Pertemuan Dirosa

Keberlanjutan Kegiatan: setelah usainya kegiatan ini tentu saja mahasiswa KKN STIBA Makassar mengadakan tindak lanjut dari kegiatan ini dengan membentuk halakah tahsinul qira'ah yang dimulai dari juz 30 .

\section{KESIMPULAN}

Kuliah Kerja Nyata (KKN) STIBA Makassar angkatan III ini adalah sebagai wujud pengabdian kepada masyarakat yang merupakan pilar dari tri dharma perguruan tinggi. Program kerja yang berhasil dicanangkan oleh mahasiswa KKN STIBA Makassar angkatan III di Desa Mangeloreng adalah sosialisasi dan silaturahim (SS), pembinaan TK/TPA, peresmian TK/TPA, pengajaran SD/SMP, kelompok belajar bahasa arab (KBBA), festival santri (FS), dan pembelajaran dirosa (PD).

Hasil dari pelaksanaan KKN ini adalah terlihat minat dan antusiasme anak-anak (santri) mengalami kemajuan dalam mempelajari al-Qur'an, ilmu agama, dan bahasa Arab. Hal ini dapat ditandai dengan bertambahnya jumlah santri yang belajar mengaji di TPA, kelompok belajar bahasa Arab dan diresmikannya 1 TPA baru, serta dukungan orang tua santri yang mengapresiasi penuh program-program edukatif mahasiswa KKN STIBA Makassar. Perkembangan keterampilan mengaji juga tampak terlihat pada 
kelompok belajar al-Qur'an orang dewasa (Dirosa), penandanya adalah kemahiran dalam pelafalan makraj dan tajwid.

\section{DAFTAR PUSTAKA}

Ahmad, Universitas, Dahlan Yogyakarta, and A Pendahuluan, 'Perlombaan Festival Anak Sholeh Masjid Al- Hidayah Sebagai Upaya Untuk Menumbuhkan Kreativitas Dan Meningkatkan Partisipasi Warga Perumahan Perwita Regency', 1.2 (2017).

Albab, Muhammad Ulil, Lia Safitri, Annisa Cahya Febriana, Ayu Sukma Hidayah, Wahyu Ananda Aziz, Dewani Roro Rengganis, and others, 'Pembentukan Taman Pendidikan Al-Qur' an ( TPA ) Untuk Mencetak Generasi Qur' Ani', 1 (2019).

Aliyyah, Rusi Rusmiati, R ST Pupu Fauziah, and Nur Asiyah, 'Peningkatan Cinta Lingkungan Dan Pemberdayaan Masyarakat Pedesaan Melalui Program Pengabdian Masyarakat', Qardhul Hasan: Media Pengabdian Kepada Masyarakat, 3.1 (2018),

An, Pendidikan Al-qur, T P A Dalam, Kemampuan Membaca, and Al-qur A N Di, Efektivitas Program Pembelajaran Taman Efektivitas Program Pembelajaran Taman Pendidikan Al-Qur 'an (Tpa) Dalam Meningkatkan Kemampuan Membaca Al-Qur ' an Di Tpa Al-Hikmah, 2017

Darussalam, A., 'Wawasan Hadis Tentang Silaturahmi A.', Jurnal Kajian Ilmu Hadis, 8.2 (2017).

Divayana, Dewa Gede Hendra, I Putu Wisna Ariawan, and P. Wayan Arta Suyasa, 'Pelaksanaan Kkn-Ppm Dalam Rangka Pemberdayaan Masyarakat Demi Mewujudkan Swadaya Pemenuhan Kebutuhan Vital Berlandaskan Semangat Ngayah', Widya Laksana, 8.2 (2019).

'Gambaran Umum Desa Mangeloreng' < http:// kampungkb. bkkbn.go.id/ kampungkb /profile /4563> [accessed 22 April 2020]

Ismail, Ismail, Hasan Hasan, and Musdalifah Musdalifah, 'Pengembangan Kompetensi Mahasiswa Melalui Efektivitas Program Magang Kependidikan', Edumaspul Jurnal Pendidikan, 2.1 (2018).

Kartini, Nurul Hikmah, Yuni Rahayu, Anita Rahman, Siti Marjanah, Dina Noor Laila Ramadhani, and Ifan Supiyani, 'Kerajinan Tikar Purun Di Kelompok Masyarakat Pimpinan Daerah Aisyiyah Kuala Pembuang Seruyan', PengabdianMu: Jurnal Ilmiah Pengabdian Kepada Masyarakat, 4.1 (2019).

Mahasiswa KKN STIBA Makassar, 'Kondisi Bidang Ekonomi. Data Hasil Pengamatan Dan Interaksi Mahasiswa Di Lokasi KKN' (Maros, 2020)

-, 'Kondisi Bidang Pendidikan. Data Hasil Pengamatan Dan Interaksi Mahasiswa Di Lokasi KKN' (Maros, 2020)

_ ' 'Kondisi Bidang Sosial, Budaya Dan Agama. Data Hasil Pengamatan Dan Interaksi Mahasiswa Di Lokasi KKN' (Maros, 2020)

_ , 'Kondisi Kesehatan, Lingkungan Hidup Dan Pariwisata. Data Hasil Pengamatan Dan Interaksi Mahasiswa Di Lokasi KKN' (Maros, 2020)

'Mangeloreng, Bantimurung, Maros - Wikipedia Bahasa Indonesia, Ensiklopedia Bebas' 
WAHATUL MUJTAMA': Jurnal Pengabdian Masyarakat

Vol. 1, No. 1 (2020) : Hal. 13-32

Website: https://journal.stiba.ac.id

<https://id.wikipedia.org/wiki/Mangeloreng,_Bantimurung,_Maros> [accessed 22 April 2020]

Perdana, Amelia, M.Si Drs. Holilulloh, M.Si Drs. Holilulloh, and S.Pd, M.Pd Yunisca Nurmalisa, Pengaruh Pelaksanaan Kuliah Kerja Nyata Terhadap Keterampilan Sosial Mahasiswa Program Studi Ppkn, 25 July 2013, I

'Profil Desa Desa Mangeloreng Kecamatan Bantimurung Kabupaten Maros Tahun 2019' (Maros, 2019).

Saddang, Muhammad, 'Implementasi Metode Dirosa Dalam Pembelajaran Al-Qur'ān Dewan Pimpinan Daerah Wahdah Islamiyah Makassar', 2018.

Sholeh, Muhammad, and Untung Joko Basuki, 'Implementasi Program Kuliah Kerja Nyata Melalui Sosialisasi Internet Sehat Bagi Remaja Masjid Aqrob Nganjar,Wojo Kabupaten Bantul', Adimas : Jurnal Pengabdian Kepada Masyarakat, 2019.

Surakarta, Iain, 'Problematika Pebelajar Bahasa Arab Anak Usia 7 Sampai 13 Tahun Marlina Wulandari IAIN SURAKARTA', 2008, 2019. 